Article

\title{
A Kinetic Study on Combustible Coastal Debris Pyrolysis via Thermogravimetric Analysis
}

\author{
Eunhye Song ${ }^{1}$, Daegi Kim ${ }^{2, *(\mathbb{D})}$, Cheol-Jin Jeong ${ }^{1}$ and Do-Yong Kim ${ }^{3}$ \\ 1 Plant Engineering Division, Institute for Advanced Engineering, Gyeonggi-do 17180, Korea; \\ ehsong@iae.re.kr (E.S.); fejin@iae.re.kr (C.-J.J.) \\ 2 Department of Environmental Engineering, Daegu University, Gyeongbuk 38453, Korea \\ 3 Department of Environmental Engineering, Mokpo National University, Jeonnam 58554, Korea; \\ dykim1975@mokpo.ac.kr \\ * Correspondence: daegi.kim81@daegu.ac.kr; Tel.: +82-53-850-6692
}

Received: 14 January 2019; Accepted: 26 February 2019; Published: 4 March 2019

check for updates

\begin{abstract}
Coastal debris has recently emerged as a serious environmental pollution problem. Coastal debris can be treated using pyrolysis because it consists mainly of combustible materials like plastics (e.g., polyethylene (PE), polypropylene (PP), nylon) and wood. In this study, the pyrolysis characteristics of coastal debris were fully utilized by applying their basic data to fuel production. The initial temperature increased from $330^{\circ} \mathrm{C}$ to $380^{\circ} \mathrm{C}$ for the nylon fishing net coastal debris sample, from $405.01{ }^{\circ} \mathrm{C}$ to $430.08{ }^{\circ} \mathrm{C}$ for the PE fishing net coastal debris sample, from $395.01{ }^{\circ} \mathrm{C}$ to $419.96{ }^{\circ} \mathrm{C}$ for the PP rope coastal debris sample, and from $114.95^{\circ} \mathrm{C}$ to $115.02{ }^{\circ} \mathrm{C}$ for the wood (bamboo) coastal debris sample. The activation rate of the global activation energy and the pre-exponential factors rose with the increasing heating rate, complementing the reduction rate constant due to the larger growth of the exponential term due to the kinetic models used.
\end{abstract}

Keywords: coastal debris; pyrolysis; plastic waste; wood waste; kinetic model

\section{Introduction}

Marine debris consisting of manufactured or synthesized solid waste materials has given rise to a serious global issue regarding the marine environment. In particular, the ecology of marine animals and economic activities in marine areas have become cause for concern [1-3]. Marine debris refers to all types of waste floating in the sea or approaching the coast due to natural or artificial factors [3-5]. Coastal, sink, and floating marine debris types consist of coastal, sea-based waste generated from human activities, and foreign wastes introduced to the domestic marine areas and coasts from overseas sources [3-7].

According to a survey conducted by the Ministry of Oceans and Fisheries of South Korea, more than 176,000 tons of marine debris were generated in South Korea in 2012, but only 58,000 tons were collected, gradually worsening the problem of marine debris in the country [8]. Statistical data from the Marine Litter Integrated Information System showed that approximately 78,000 tons of marine debris were collected in 2016. Among these, 53\% were coastal debris, 34.1\% were underwater deposited waste, $6.6 \%$ were floating wastes, and $6.3 \%$ were disaster wastes [8]. Due to the geographic conditions of South Korea, the Kuroshio Current flowing from the East China Sea to Japan's east coast induces the marine debris of neighboring countries to pass through South Korea [9,10]. All the coastal debris are potentially pushed toward the coast by winds and typhoons, among others. Of these coastal debris, 54\% are plastics (e.g., wire ropes, waste nets), 7.9\% are timber, 19\% are incombustible materials (including metal and glass), and 18\% are other types of material [10-12]. Marine debris contains long-term decay-resistant materials such as waste fishing nets, waste ropes, Styrofoam buoys, and various types of plastics depending on the sources (e.g., municipal solid waste, industrial wastes, 
and marine wastes), which threaten the marine environment and ecosystem as well as cause marine resource damage and marine accidents $[5,11,13]$. According to its composition, however, coastal debris also have a high calorific value of approximately $6000 \mathrm{kcal} / \mathrm{kg}$, which can be applied to the high-efficiency energy industry $[14,15]$.

For coastal debris consisting of combustible materials like plastics and wood, pyrolysis and combustion may be considered attractive treatment alternatives $[11,13,16]$. The recycling of waste plastic of coastal debris via pyrolysis involves thermal degradation of the polymeric material in the absence of oxygen to produce useful fuels [12-14]. These treatment techniques can reduce coastal debris volume and can boost energy and/or chemical production. The thermal characteristics of coastal debris can provide effective usage and controlled conditions for incinerators and cement kilns. In addition, pyrolysis can solve the problem of coastal debris treatment because coastal debris consists mainly of plastics (e.g., polyethylene (PE), polypropylene (PP), nylon) as well as some types of wood.

In this study, the pyrolysis characteristics of coastal debris were fully utilized by applying their basic data to the fuel production system. The changes in the pyrolysis characteristics and kinetics of several plastics and wood making up coastal debris were studied through thermogravimetric (TG) analysis.

\section{Materials and Methods}

\subsection{Materials}

For this study, three plastic coastal debris samples (two fishing nets made of nylon and PE, respectively, and one rope made of PP) and wood coastal debris samples (bamboo) were collected from the south-west coastal area of South Korea and were investigated. In 2016, 32\% of the marine wastes were collected in this area. Marine wastes particularly abound in Sinan-gun, which consists of more than 1000 islands and produce a large amount of waste fishing gear since fishery and aquaculture activities abound there. In addition, since it is located farther toward the south-west coastal area of South Korea, marine wastes, including foreign wastes, are pushed toward the coast.

The characteristics of the study samples were subjected to ultimate, proximate, and calorific value analyses. The results of such analyses are shown in Table 1 .

Table 1. Characteristics of the plastic and wood coastal debris samples.

\begin{tabular}{|c|c|c|c|c|c|}
\hline \multicolumn{2}{|c|}{ Category } & $\begin{array}{c}\text { Nylon } \\
\text { (Fishing Net) }\end{array}$ & $\begin{array}{l}\text { PE (Fishing } \\
\text { Net) }\end{array}$ & $\begin{array}{c}\text { PP } \\
\text { (Rope) }\end{array}$ & $\begin{array}{c}\text { Waste Wood } \\
\text { (Bamboo) }\end{array}$ \\
\hline \multicolumn{2}{|c|}{ Moisture content (wt. \%) ${ }^{a}$} & 2.3 & 1.4 & 1.3 & 7.3 \\
\hline \multirow{3}{*}{$\begin{array}{c}\text { Proximate } \\
\text { analysis (wt. \%) }{ }^{b}\end{array}$} & Volatile matter & 95.3 & 96.4 & 93.8 & 75.2 \\
\hline & Fixed carbon & 0.3 & 0.1 & 0.2 & 21.3 \\
\hline & Ash & 0.4 & 3.5 & 6 & 3.5 \\
\hline \multirow{5}{*}{$\begin{array}{l}\text { Ultimate analysis } \\
\qquad(w t . \%)^{b}\end{array}$} & Carbon & 63.1 & 82.4 & 80.1 & 48.3 \\
\hline & Hydrogen & 8.4 & 13.2 & 12.9 & 5.9 \\
\hline & Oxygen & 17.9 & 0.7 & 0.8 & 39.4 \\
\hline & Nitrogen & 10.2 & 0.2 & 0.2 & 0.4 \\
\hline & $\mathrm{Cl}^{-}$ & 0.1 & 0.3 & 0.3 & 2.8 \\
\hline \multicolumn{2}{|c|}{ Calorific value $(\mathrm{kcal} / \mathrm{kg})^{\mathrm{b}}$} & 9884 & 10,406 & 10,876 & 4201 \\
\hline
\end{tabular}

\subsection{TG Run for Pyrolysis Analysis}

The TG analysis of the pyrolysis behavior was carried out using a thermogravimetric analyzer (Seiko, Exstar 6000, TG/DTA6100, Tokyo, Japan). For each run, $1 \pm 0.2 \mathrm{mg}$ of each study sample was prepared. The TG results provided the function of temperature for the plastic and wood coastal debris samples with non-isothermal conditions, and a controlled heating program $\left(5,10\right.$, and $\left.20^{\circ} \mathrm{C} \cdot \mathrm{min}^{-1}\right)$ was used from room temperature up to $800^{\circ} \mathrm{C}$. The decomposition temperatures were measured under 
dynamic conditions in a nitrogen atmosphere with a total flow rate of $100 \mathrm{~mL} \cdot \mathrm{min}^{-1}$. A sample of about $10 \mathrm{mg}$ was placed in a platinum crucible prior to analysis. Moreover, differential thermography (DTG) results showed the characteristics of the pyrolysis behavior of coastal debris.

\subsection{Non-Isothermal Kinetics}

There are two main approaches to kinetic modeling pyrolysis. The first approach consists of the use of network models like the chemical percolation devolatilization (CPD), FLASHCHAIN, and FG-DVC models, which have been developed to accurately describe the complex process behavior of coal and biomass pyrolysis $[17,18]$. They consist of complicated mathematical models. However, carrying out the complex computation takes time. The second approach, on the other hand, consists of the use of global models and is easy to utilize due to its computational simplicity. These simple global kinetic models have been widely used in many studies (e.g., Andrew P. [19], Fei et al. [20], and Piyarat et al. [21]) to study the behavior of the pyrolysis process. Accordingly, the global pyrolysis kinetic models were adopted in this study. They are classified into three categories: the one-, two-, and multi-step models. The number of steps in each model indicates the number of reaction kinetic pathways occurring during the whole process. For the plastic coastal debris study samples, the one-step model was employed to estimate the kinetic parameters for the overall pyrolysis process. For the wood coastal debris sample, the nth-order reaction model function was utilized to describe the complex pyrolysis process by computing the order of the process. The multi-step kinetics model was used to estimate the pyrolysis process behavior of the sample with three main components: cellulose, hemicellulose, and lignin. The conversion $(\alpha)$ of the plastic coastal debris in the overall pyrolysis process can be calculated using the formula below.

$$
\alpha_{i}=\frac{W_{i, 0}-W_{i}}{W_{i, 0}-W_{i, \infty}}
$$

where $W_{0}, W$, and $W$ represent the instantaneous, initial, and final weights of the sample in the pyrolysis process, respectively. The subscript $i$ indicates each step of the multi-step model, and unity in the single-step model.

The global kinetics model form can be described by the Arrhenius equation [22] shown below.

$$
\frac{d \alpha_{i}}{d t}=\mathrm{A}_{i} \exp \left(-\frac{E_{i}}{R T}\right)\left(1-\alpha_{i}\right)^{n_{i}}
$$

where $t$ is the given time (s), $A$ is the pre-exponential factor $\left(\mathrm{min}^{-1}\right), E_{a}$ is the apparent activation energy $\left(\mathrm{kJ} \cdot \mathrm{mol}^{-1}\right), R$ is the universal gas constant $\left(8.314 \mathrm{~J} \cdot \mathrm{mol}^{-1} \cdot \mathrm{K}^{-1}\right), \mathrm{T}$ is the absolute temperature $(\mathrm{K})$, and $n$ is the order of the reaction function. In this study, the $n$ th-order reaction model function indicates complexity of different marine debris pyrolysis processes. The pyrolysis process of marine debris proceeds in a non-isothermal condition considering a constant heating value $(\beta=d T / d t)$ in this study. Accordingly, Equation (2) was converted to Equation (3).

$$
\frac{d \alpha_{i}}{d T}=\frac{\mathrm{A}_{i}}{\beta} \exp \left(-\frac{E_{i}}{R T}\right)\left(1-\alpha_{i}\right)^{n_{i}}
$$

The conversion and kinetic equations of the multi-step model were calculated by the sum of the individual steps shown below.

$$
\begin{gathered}
\alpha=\sum_{i} y_{i} \alpha_{i} \\
\frac{d \alpha}{d T}=\sum_{i} y_{i} \frac{d \alpha_{i}}{d T} \\
\sum_{i} y_{i}=1
\end{gathered}
$$


where the subscript $i$ indicates each step of the multi-step model and $y_{i}$ represents the contribution of the individual process to the overall weight loss. The uncharted kinetic parameters and contribution factors were computed by estimating the experimental data through non-linear least-squares analysis. The optimization was performed in MATLAB (R2015a, The MathWorks, Inc, Natick, MA, USA) to minimize the sum of squared residuals $(S)$, and the deviations between the experiment data and the predicted values were calculated using the equations below.

$$
\begin{aligned}
& S=\sum_{j=1}^{N_{d}}\left(\left(\frac{d \alpha}{d t}\right)_{j}^{e}-\left(\frac{d \alpha}{d t}\right)_{j}^{c}\right)^{2} \\
& \text { Devi. }(\%)=100 \times \sqrt{\frac{S}{N_{d}-N_{p}}}
\end{aligned}
$$

\section{Results and Discussion}

\subsection{Thermogravimetric Analysis of Coastal Debris}

The TG and DTG curves as a function of temperature for the plastic and wood coastal debris samples under non-isothermal conditions (as 5, 10, and $20^{\circ} \mathrm{C} \cdot \mathrm{min}^{-1}$ ) are presented in Figures 1 and 2 .

When the study samples were heated from room temperature to $100{ }^{\circ} \mathrm{C}$, the weight of the wood coastal debris sample decreased mainly because of the evaporation of the surface and some inherent moisture while the weight loss of the plastic coastal debris samples was negligible. With the continuously increasing temperature, major degradations were observed after the drying stage. In this study, the drying stage was not considered to exclude the effects of the water contents. Therefore, the variations in weight and kinetic parameter were analyzed based on the completely dried samples.

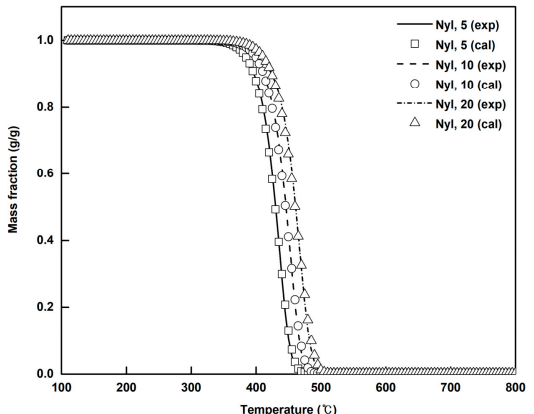

(a)

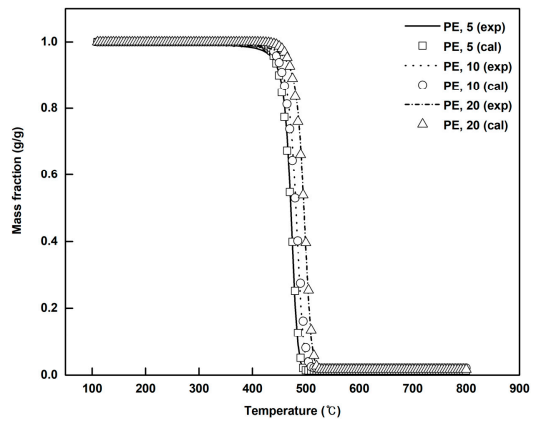

(c)

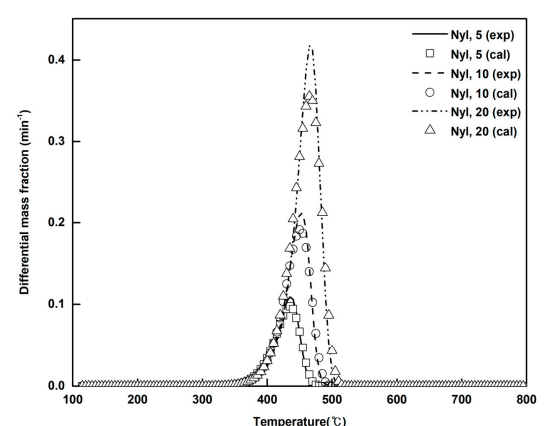

(b)

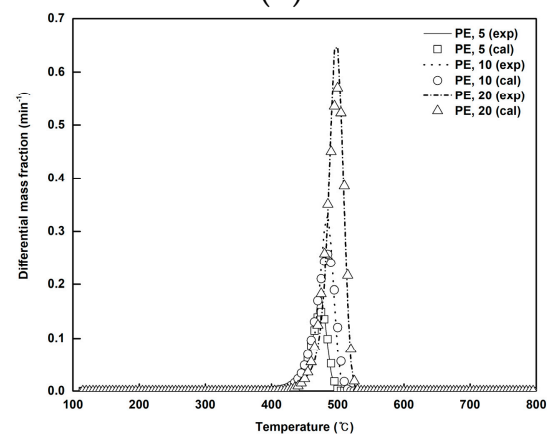

(d)

Figure 1. Cont. 


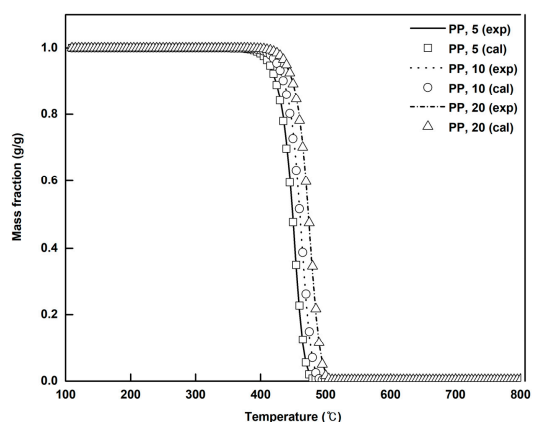

(e)

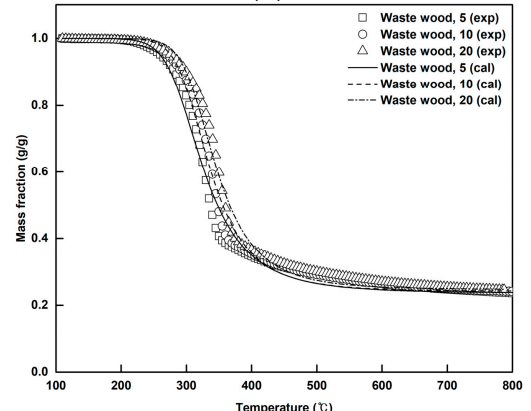

(g)

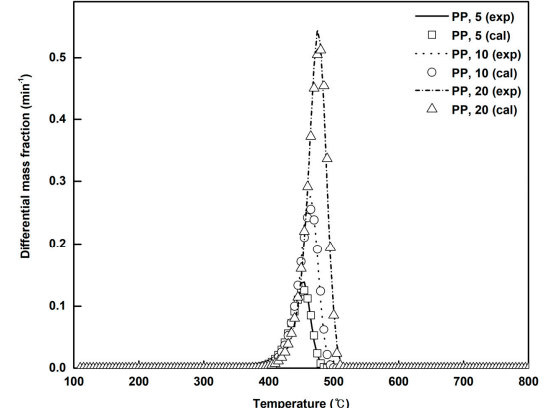

(f)

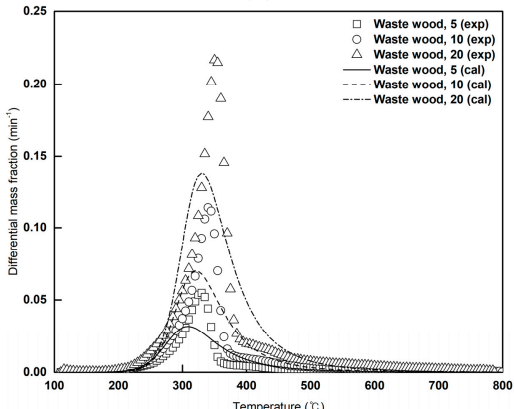

(h)

Figure 1. Experimental and calculated (one-step model) pyrolytic thermogravimetric (TG) (a) and differential thermography (DTG) (b) curves of the nylon fishing net coastal debris sample. TG (c) and DTG (d) curves of the PE fishing net coastal debris sample. TG (e) and DTG (f) curves of the PP rope coastal debris sample. TG (g) and DTG (h) curves of the wood (bamboo) coastal debris sample at different heating rates.

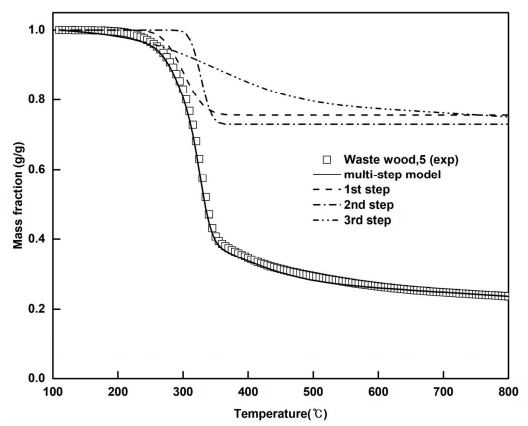

(a)

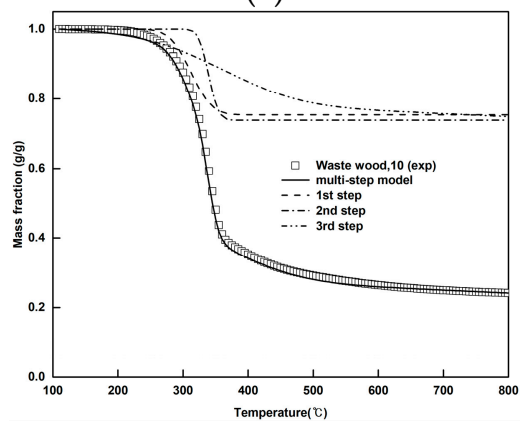

(c)

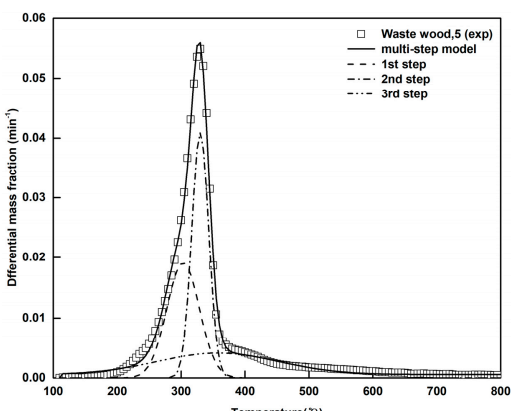

(b)

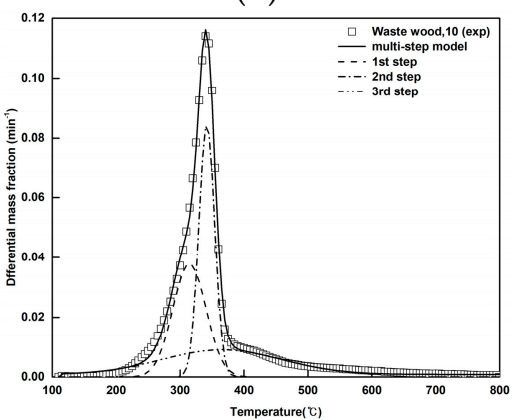

(d)

Figure 2. Cont. 


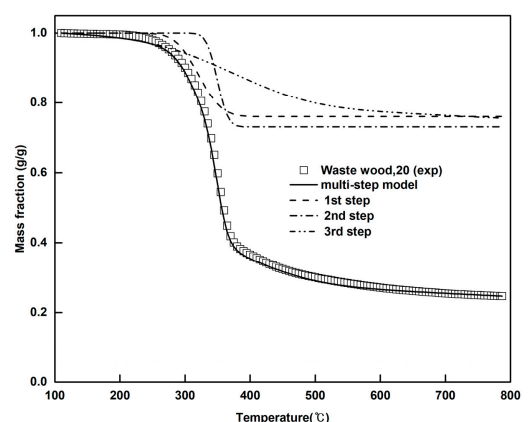

(e)

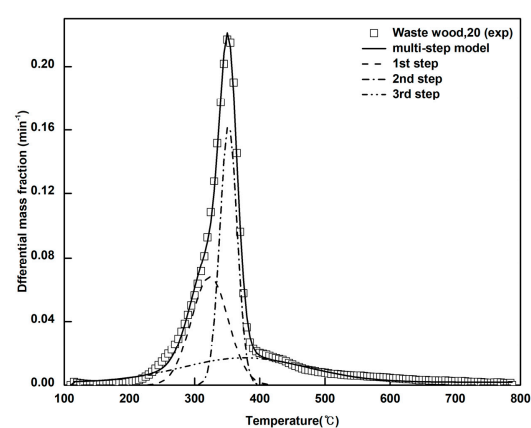

(f)

Figure 2. Experimental and calculated (multi-step model) pyrolytic TG and DTG curves of the wood coastal debris sample: (a) TG and (b) DTG curves at a $5{ }^{\circ} \mathrm{C}$ heating rate, (c) TG and (d) DTG curves at $10{ }^{\circ} \mathrm{C}$ heating rate, and (e) TG and (f) DTG curves at a $20^{\circ} \mathrm{C}$ heating rate.

The TG and DTG curves of all the three plastic coastal debris samples were similar, while those of the wood coastal debris sample showed discrepancy since the DTG curves of the former were perceived to be symmetric. However, the latter was perceived to have had an asymmetrical shape. This was attributed to the thermally decomposed main constituent. Plastic is a polymer consisting of a certain monomer, such as nylon $\left(\mathrm{C}_{6} \mathrm{H}_{11} \mathrm{NO}\right)_{n}, \mathrm{PE}\left(\mathrm{C}_{2} \mathrm{H}_{4}\right)_{n}, \mathrm{PP}\left(\mathrm{C}_{3} \mathrm{H}_{6}\right)$. On the other hand $[15,23]$, wood mainly consists of a high molecular compound of cellulose, hemicellulose, and lignin [24-26]. In addition, the main thermal decomposition of the plastic coastal debris samples occurred within a narrow temperature range of 330 to $535^{\circ} \mathrm{C}$ whereas the main weight loss of the wood coastal debris sample proceeded within a broad temperature range of 115 to $779{ }^{\circ} \mathrm{C}$. This was due to the main component of pyrolysis $[25,27]$.

\subsection{Effect of the Heating Rate on the Pyrolysis Process of Coastal Debris}

As shown in Tables 2 and 3, the pyrolysis characteristics of coastal debris were examined based on each TG analysis condition.

The maximum weight loss temperature $\left(T_{m}\right)$, maximum weight loss rate $\left(R_{m}\right)$, gaseous species release rate, and initial $\left(T_{i}\right)$ and final $\left(T_{f}\right)$ temperatures were influenced by the different heating rates and clearly shifted toward the high-temperature range $[18,28]$. The tendencies were described based on the heat and mass transfer resistance. In addition, the particle size limited the mass and heat transfer. Accordingly, to reduce the resistance, samples with a small particle size were selected for all the experiments. The effluences of the heating rate were a significant factor in the pyrolysis due to the variations of the heat and mass transfer inside or among the sample particles [27,29].

Table 2. Characteristics of the plastic coastal debris samples in the pyrolysis process.

\begin{tabular}{ccccccc}
\hline Sample & $\boldsymbol{\beta}\left({ }^{\circ} \mathbf{C} \cdot \mathbf{m i n}^{-\mathbf{1}}\right)$ & $\boldsymbol{T}_{\boldsymbol{i}}\left({ }^{\circ} \mathbf{C}\right)$ & $\boldsymbol{T}_{\boldsymbol{m}}\left({ }^{\circ} \mathbf{C}\right)$ & $\boldsymbol{T}_{f}\left({ }^{\circ} \mathbf{C}\right)$ & $\boldsymbol{R}_{\boldsymbol{m}}\left(\mathbf{m i n}^{-\mathbf{1}}\right)$ & $\boldsymbol{M}_{f}(\mathrm{~g} / \mathrm{g})$ \\
\hline \multirow{2}{*}{ Nylon } & 5 & 330.00 & 434.98 & 475.01 & 0.1088 & 0.4803 \\
fishing net & 10 & 370.00 & 454.94 & 494.98 & 0.2116 & 0.2012 \\
& 20 & 380.06 & 464.98 & 520.05 & 0.4169 & 0.3108 \\
\hline \multirow{2}{*}{ PE fishing } & 5 & 405.01 & 474.97 & 505.02 & 0.1785 & 1.4043 \\
net & 10 & 410.07 & 484.92 & 515.07 & 0.3310 & 2.1120 \\
& 20 & 430.08 & 499.96 & 535.16 & 0.6475 & 1.6969 \\
\hline \multirow{2}{*}{ PP rope } & 5 & 395.01 & 455.02 & 490.01 & 0.1387 & 0.4935 \\
& 10 & 405.01 & 465.01 & 505.02 & 0.2760 & 0.2638 \\
& 20 & 419.96 & 474.97 & 520.03 & 0.5450 & 0.4641 \\
\hline
\end{tabular}


Table 3. Characteristics of the wood coastal debris sample in the pyrolysis process.

\begin{tabular}{|c|c|c|c|c|c|c|c|}
\hline Sample & $\beta\left({ }^{\circ} \mathrm{C} \cdot \min ^{-1}\right)$ & Regime & $T_{i}\left({ }^{\circ} \mathrm{C}\right)$ & $T_{m}\left({ }^{\circ} \mathrm{C}\right)$ & $T_{f}\left({ }^{\circ} \mathrm{C}\right)$ & $R_{m}\left(\min ^{-1}\right)$ & $M_{f}(\mathrm{~g} / \mathrm{g})$ \\
\hline \multirow{9}{*}{$\begin{array}{l}\text { Wood (bamboo) } \\
\text { coastal debris }\end{array}$} & \multirow{3}{*}{5} & $1 \mathrm{st}$ & 224.96 & 305.01 & 390.01 & 0.0191 & 0.3540 \\
\hline & & $2 n d$ & 285.00 & 330.02 & 380.03 & 0.0410 & 0.3634 \\
\hline & & 3rd & 114.95 & 360.00 & 745.01 & 0.0042 & 0.2414 \\
\hline & \multirow{3}{*}{10} & $1 \mathrm{st}$ & 230.00 & 314.98 & 404.95 & 0.0379 & 0.8073 \\
\hline & & 2nd & 299.98 & 340.01 & 390.01 & 0.0839 & 0.3621 \\
\hline & & $3 \mathrm{rd}$ & 114.98 & 365.00 & 765.03 & 0.0091 & 0.2431 \\
\hline & \multirow{3}{*}{20} & 1st & 234.99 & 324.90 & 419.98 & 0.0680 & 0.3470 \\
\hline & & 2nd & 304.95 & 350.06 & 404.97 & 0.1613 & 0.3609 \\
\hline & & 3rd & 115.02 & 374.90 & 779.94 & 0.0169 & 0.2467 \\
\hline
\end{tabular}

As the heating rate rose from 5 to $20{ }^{\circ} \mathrm{C} \mathrm{min}^{-1}, T_{i}$ increased from $330{ }^{\circ} \mathrm{C}$ to $380{ }^{\circ} \mathrm{C}$ for the nylon fishing net coastal debris sample, from $405.01{ }^{\circ} \mathrm{C}$ to $430.08{ }^{\circ} \mathrm{C}$ for the PE fishing net coastal debris sample, from $395.01{ }^{\circ} \mathrm{C}$ to $419.96{ }^{\circ} \mathrm{C}$ for the PP and the rope coastal debris sample, and from $114.95{ }^{\circ} \mathrm{C}$ to $115.02{ }^{\circ} \mathrm{C}$ for the wood coastal debris sample. The $T_{i}$ values of the PP and PE coastal debris showed lower initial pyrolysis temperatures than in other studies [30-33]. The initiation of thermal decomposition for PP occurred at a lower temperature than for PE because the polymer chain of the PP coastal debris sample consists of a tertiary carbon, which corresponds to branching $[13,29]$. Furthermore, $T_{m}$ increased from $434.98{ }^{\circ} \mathrm{C}$ to $464.98^{\circ} \mathrm{C}$ for the nylon, from $474.97^{\circ} \mathrm{C}$ to $499.96{ }^{\circ} \mathrm{C}$ for the PE, from $455.02{ }^{\circ} \mathrm{C}$ to $475.97{ }^{\circ} \mathrm{C}$ for the PP, and from $360.00{ }^{\circ} \mathrm{C}$ to $374.90{ }^{\circ} \mathrm{C}$ for the wood (bamboo) coastal debris sample. The polymers with branching are weak and more breakable than linear polymers like PE. $T_{i}$ of PP and PE of coastal debris showed lower initial pyrolysis temperature than in the other study [30]. The DTG peak temperature of PP of marine debris were observed to be lower than those of Gunasee et al. [31]. Meanwhile, the profile of thermal composition on waste wood is in good agreement with results from earlier studies [32].

\subsection{Decomposition Curves in the Kinetic Models}

The apparent kinetic parameters were estimated using two kinds of global kinetic models (oneand multi-step models) for the plastic and wood coastal debris samples, respectively. The conversion of the coastal debris as a function of temperature is shown in Figures 1 and 2, and the optimized kinetic parameters are listed in Tables 4 and 5.

For the plastic coastal debris samples, single-step degradation took place due to the compound constituted as stated previously. The global activation energies $\left(E_{a}\right)$ were estimated to be 212.95-218.17, 336.20-389.78, and 297.03-326.14 $\mathrm{kg} \cdot \mathrm{mol}^{-1}$ for the nylon, PE, and PP coastal debris samples, respectively, as shown in Table 4 . The $E_{a}$ of the PE and PP are in good agreement with the experimental data reported by various authors [33-37]. The activation energy of the PE was higher than that of PP due to the residue yields in three major products: plastic derived oil, gas, and residue wax $[14,15]$. The pyrolysis of the PE coastal debris sample produced a higher yield of wax residue compared to that of the PP coastal debris sample and it needed more activation energy due to the inorganic/char content and incomplete conversion of PE [15,38]. The activation rate of the global activation energies $\left(E_{a}\right)$ and the pre-exponential factors $(A)$ rose with the increasing heating rates to complement the reduction rate constant due to the larger growth of the exponential term. The pyrolysis process of the wood coastal debris sample was analyzed using the multi-step reaction kinetic model, as shown in Figure 2. The global kinetic reaction order of the sample was found to be higher than unity and such a high value points to a measure of multiplicity and complexity of the reaction mechanism [17,18]. In addition, the regression coefficients $\left(r^{2}\right)$ were lower than 0.7896, which implies that the multi-step reaction kinetic model is inadequate for describing the pyrolysis behavior of the wood coastal debris sample. On the other hand, the three-step kinetic model could describe the behavior of the three independent one-step decomposition mechanisms for cellulose, hemicellulose, and lignin. The temperature ranges 
of the individual decomposition components were found to be in good agreement with the values obtained from previous studies $[25,27]$.

Table 4. Kinetic parameters of the plastic coastal debris samples in the pyrolysis process at different heating rates.

\begin{tabular}{cccccc}
\hline Sample & $\boldsymbol{\beta}\left({ }^{\circ} \mathbf{C} / \mathbf{m i n}\right)$ & $\boldsymbol{E}_{\boldsymbol{a}}\left(\mathbf{k J} \cdot \mathbf{m o l}^{-\mathbf{1}}\right)$ & $\boldsymbol{A}\left(\mathbf{m i n}^{-\mathbf{1}}\right)$ & $\boldsymbol{r}^{\mathbf{2}} \mathbf{( - )}$ & $\boldsymbol{S} \mathbf{( \% )}$ \\
\hline \multirow{2}{*}{$\begin{array}{c}\text { Nylon fishing } \\
\text { net }\end{array}$} & 5 & 212.95 & $1.22 \times 10^{15}$ & 0.9892 & 0.2411 \\
& 10 & 217.98 & $2.50 \times 10^{15}$ & 0.9889 & 0.4783 \\
\hline \multirow{3}{*}{ PE fishing net } & 20 & 218.17 & $7.30 \times 10^{15}$ & 0.9827 & 1.1865 \\
\hline \multirow{3}{*}{ PP rope } & 5 & 336.20 & $9.77 \times 10^{22}$ & 0.9737 & 0.4838 \\
& 20 & 380.28 & $1.37 \times 10^{26}$ & 0.9587 & 1.1520 \\
& 5 & 389.78 & $3.24 \times 10^{26}$ & 0.9798 & 1.6053 \\
\hline & 10 & 297.03 & $7.28 \times 10^{20}$ & 0.9925 & 0.2214 \\
& 20 & 309.67 & $5.33 \times 10^{21}$ & 0.9913 & 0.4837 \\
\end{tabular}

Table 5. Kinetic parameters of the wood coastal debris sample in the pyrolysis process at different heating rates.

\begin{tabular}{|c|c|c|c|c|c|c|c|c|}
\hline Sample & $\beta\left({ }^{\circ} \mathrm{C} / \mathrm{min}\right)$ & Regime & $N(-)$ & $E(\mathrm{~kJ} / \mathrm{mol})$ & $A\left(\min ^{-1}\right)$ & $r^{2}(-)$ & $S(\%)$ & $y_{i}(-)$ \\
\hline \multirow{12}{*}{$\begin{array}{c}\text { Wood } \\
\text { (bamboo) } \\
\text { coastal debris } \\
\text { sample }\end{array}$} & \multirow{4}{*}{5} & Global & 3.2 & 119.01 & $8.16 \times 10^{9}$ & 0.7727 & 0.5529 & - \\
\hline & & 1st & 1.2 & 112.97 & $5.52 \times 10^{9}$ & 0.9976 & 0.3932 & 0.3195 \\
\hline & & 2nd & 1.2 & 259.97 & $2.02 \times 10^{22}$ & 0.9884 & 0.6884 & 0.3544 \\
\hline & & $3 \mathrm{rd}$ & 1.4 & 24.11 & 4.55 & 0.9843 & 0.2185 & 0.0055 \\
\hline & \multirow{4}{*}{10} & Global & 3.2 & 138.85 & $6.30 \times 10^{11}$ & 0.7896 & 1.0581 & - \\
\hline & & 1 st & 1.4 & 141.38 & $1.57 \times 10^{12}$ & 0.9980 & 0.7095 & 0.3246 \\
\hline & & 2nd & 1.2 & 274.29 & $4.86 \times 10^{22}$ & 0.9878 & 1.3794 & 0.3447 \\
\hline & & $3 \mathrm{rd}$ & 1.6 & 31.21 & $2.59 \times 10$ & 0.9850 & 0.3987 & 0.0120 \\
\hline & \multirow{4}{*}{20} & Global & 3.2 & 141.82 & $1.46 \times 10^{12}$ & 0.7876 & 2.0686 & - \\
\hline & & $1 \mathrm{st}$ & 1.6 & 144.70 & $2.20 \times 10^{12}$ & 0.9994 & 1.4814 & 0.3181 \\
\hline & & 2nd & 1.2 & 300.07 & $1.79 \times 10^{25}$ & 0.9904 & 2.7466 & 0.3575 \\
\hline & & $3 \mathrm{rd}$ & 2 & 44.30 & $3.96 \times 10^{2}$ & 1.0000 & 0.8037 & 0.0224 \\
\hline
\end{tabular}

\section{Conclusions}

In this study, the pyrolysis characteristics of coastal debris were fully utilized by applying their basic data to the fuel production system. For this, the pyrolysis behaviors and kinetics of the plastic and wood coastal debris study samples were examined using thermogravimetric analysis.

The coastal debris samples that were used in this study consisted of plastics (polyethylene (PE), polypropylene (PP), and nylon) and wood, which are both incombustible. The initial temperature increased from $330{ }^{\circ} \mathrm{C}$ to $380{ }^{\circ} \mathrm{C}$ for the nylon fishing net coastal debris sample, from $405.01{ }^{\circ} \mathrm{C}$ to $430.08{ }^{\circ} \mathrm{C}$ for the PE fishing net coastal debris sample, from $395.01{ }^{\circ} \mathrm{C}$ to $419.96{ }^{\circ} \mathrm{C}$ for the PP rope coastal debris sample, and from $114.95^{\circ} \mathrm{C}$ to $115.02^{\circ} \mathrm{C}$ for the wood (bamboo) coastal debris sample. The maximum weight loss temperature increased from $434.98^{\circ} \mathrm{C}$ to $464.98^{\circ} \mathrm{C}$ for nylon, from $474.97^{\circ} \mathrm{C}$ to $499.96{ }^{\circ} \mathrm{C}$ for PE, from $455.02{ }^{\circ} \mathrm{C}$ to $475.97^{\circ} \mathrm{C}$ for PP, and from $360.00{ }^{\circ} \mathrm{C}$ to $374.90{ }^{\circ} \mathrm{C}$ for waste wood. Furthermore, the activation rate of the global activation energy and the pre-exponential factors rose with the increasing heating rates, which complemented the reduction rate constant due to the larger growth of the exponential term because of the kinetic models used.

Author Contributions: Conceptualization, D.K. Methodology, D.K. and D.-Y.K. Software, E.S. Validation, D.K., E.S., and C.-J.J. Formal analysis, C.-J.J. Investigation, D.K. and D.-Y.K. Resources, C.-J.J., D.K., and E.S. Data curation, D.K. and E.S. Writing-original draft preparation, D.K. and E.S. Writing-review and editing, D.K. Supervision, D.K. Project administration, D.K. 
Acknowledgments: This work was supported by the New \& Renewable Energy of the Korea Institute of Energy Technology Evaluation and Planning (KETEP) grant funded by the Korea government Ministry of Knowledge Economy (No. 20163030106670).

Conflicts of Interest: The authors declare no conflict of interest. The funders had no role in the design of the study; in the collection, analyses, or interpretation of data; in the writing of the manuscript, and in the decision to publish the results.

\section{References}

1. Wilcox, C.; Van Sebille, E.; Hardesty, B.D. Threat of plastic pollution to seabirds is global, pervasive, and increasing. Proc. Nat. Acad. Sci. USA 2015, 112, 11899-11904. [CrossRef] [PubMed]

2. Auta, H.S.; Emenike, C.U.; Fauziah, S.H. Distribution and importance of microplastics in the marine environment: A review of the sources, fate, effects, and potential solutions. Environ. Int. 2017, 102, 165-176. [CrossRef] [PubMed]

3. Galgani, F.; Hanke, G.; Maes, T. Global distribution, composition and abundance of marine litter. In Marine Anthropogenic Litter; Bergmann, M., Gutow, L., Klages, M., Eds.; Springer: Berlin, Germany, 2015; pp. 29-56.

4. Derraik, J.G. The pollution of the marine environment by plastic debris: A review. Mar. Pollut. Bull. 2002, 44, 842-852. [CrossRef]

5. Iñiguez, M.E.; Conesa, J.A.; Fullana, A. Pollutant content in marine debris and characterization by thermal decomposition. Mar. Pollut. Bull. 2017, 117, 359-365.

6. Gall, S.C.; Thompson, R.C. The impact of debris on marine life. Mar. Pollut. Bull. 2015, 92, 170-179. [CrossRef] [PubMed]

7. Watabe, Y.; Mizoue, K.; Oki, T.; Ukai, A.; Mitarai, Y. Interpretation of construction management data recorded during installation of cutoff sheet pile wall in coastal waste reclamation facilities. Jpn. Geotech. Soc. Spec. Publ. 2015, 3, 97-102. [CrossRef]

8. Marine Litter Information System [Internet]. Marine Litter statistics reports, Korea. Available online: https:/ / www.malic.or.kr/rest/monitoring/year/null/null/null/ (accessed on 4 April 2017).

9. Kusui, T.; Noda, M. International survey on the distribution of stranded and buried litter on beaches along the Sea of Japan. Mar. Pollut. Bull. 2003, 47, 175-179. [CrossRef]

10. Kim, D.; Kim, D.Y.; Son, M.A. Study on physicochemical characteristics of coastal wastes in island areas. J. Korean Soc. Environ. Technol. 2017, 18, 259-266.

11. Iñiguez, M.E.; Conesa, J.A.; Fullana, A. Marine debris occurrence and treatment: A review. Renew. Sustain. Energy Rev. 2016, 64, 394-402.

12. Pietrelli, L.; Poeta, G.; Battisti, C.; Sighicelli, M. Characterization of plastic beach debris finalized to its removal: A proposal for a recycling scheme. Environ. Sci. Pollut. Res. Int. 2017, 24, 16536-16542. [CrossRef] [PubMed]

13. Tondl, G.; Bonell, L.; Pfeifer, C. Thermogravimetric analysis and kinetic study of marine plastic litter. Mar. Pollut. Bull. 2018, 133, 472-477. [CrossRef] [PubMed]

14. Encinar, J.M.; González, J.F. Pyrolysis of synthetic polymers and plastic wastes: kinetic study. Fuel Process. Technol. 2008, 89, 678-686. [CrossRef]

15. Kunwar, B.; Cheng, H.N.; Chandrashekaran, S.R.; Sharma, B.K. Plastics to fuel: A review. Renew. Sustain. Energy Rev. 2016, 54, 421-428. [CrossRef]

16. Lam, S.S.; Liew, R.K.; Jusoh, A.; Chong, C.T.; Ani, F.N.; Chase, H.A. Progress in waste oil to sustainable energy, with emphasis on pyrolysis techniques. Renew. Sustain. Energy Rev. 2016, 53, 741-753. [CrossRef]

17. Ferreiro, A.I.; Giudicianni, P.; Grottola, C.M.; Rabaçal, M.; Costa, M.; Ragucci, R. Unresolved issues on the kinetic modeling of pyrolysis of woody and nonwoody biomass fuels. Energy Fuels 2017, 31, 4035-4044. [CrossRef]

18. Rabaçal, M.; Costa, M.; Vascellarib, M.; Hasseb, C. Kinetic modelling of sawdust and beech wood pyrolysis in drop tube reactors using advanced predictive models. Chem. Eng. 2014, 37, 79-84.

19. Richards, A.P.; Fletcher, T.H. A comparison of simple global kinetic models for coal devolatilization with the CPD model. Fuel 2016, 185, 171-180. [CrossRef]

20. Yao, F.; Wu, Q.; Zhou, D. Thermal decomposition of natural fibers: Global kinetic modeling with nonisothermal thermogravimetric analysis. J. Appl. Polym. Sci. 2009, 114, 834-842. [CrossRef] 
21. Weerachanchai, P.; Tangsathitkulchai, C.; Tangsathitkulchai, M. Comparison of pyrolysis kinetic models for thermogravimetric analysis of biomass. Suranaree J. Sci. Technol. 2010, 17, 387-400.

22. Varhegyi, G.; Antal, M.J., Jr.; Jakab, E.; Szabó, P. Kinetic modeling of biomass pyrolysis. J. Anal. Appl. Pyrolysis 1997, 42, 73-87. [CrossRef]

23. Jung, M.R.; Horgen, F.D.; Orski, S.V.; Rodriguez, V.; Beers, K.L.; Balazs, G.H.; Royer, S.J.; Hyrenbach, K.D.; Jensen, B.A.; Lynch, J.M. Validation of ATR FT-IR to identify polymers of plastic marine debris, including those ingested by marine organisms. Mar. Pollut. Bull. 2018, 127, 704-716. [CrossRef] [PubMed]

24. Mishra, R.K.; Mohanty, K. Pyrolysis kinetics and thermal behavior of waste sawdust biomass using thermogravimetric analysis. Bioresour. Technol. 2018, 251, 63-74. [CrossRef] [PubMed]

25. Stefanidis, S.D.; Kalogiannis, K.G.; Iliopoulou, E.F.; Michailof, C.M.; Pilavachi, P.A.; Lappas, A.A. A study of lignocellulosic biomass pyrolysis via the pyrolysis of cellulose, hemicellulose and lignin. J. Anal. Appl. Pyrolysis 2014, 105, 143-150. [CrossRef]

26. Kim, D.; Lee, K.; Park, K.Y. Upgrading the characteristics of biochar from cellulose, lignin, and xylan for solid biofuel production from biomass by hydrothermal carbonization. J. Ind. Eng. Chem. 2016, 42, 95-100. [CrossRef]

27. Várhegyi, G.; Bobály, B.; Jakab, E.; Chen, H. Thermogravimetric study of biomass pyrolysis kinetics. A distributed activation energy model with prediction tests. Energy Fuels 2010, 25, 24-32. [CrossRef]

28. Riley, J.; Siriwardane, R.; Tian, H.; Benincosa, W.; Poston, J. Kinetic analysis of the interactions between calcium ferrite and coal char for chemical looping gasification applications: Identifying reduction routes and modes of oxygen transfer. Appl. Energy 2017, 201, 94-110. [CrossRef]

29. Paraschiv, M.; Kuncser, R.; Tazerout, M.; Prisecaru, T. New energy value chain through pyrolysis of hospital plastic waste. Appl. Therm. Eng. 2015, 87, 424-433. [CrossRef]

30. Anene, A.; Fredriksen, S.; Sætre, K.; Tokheim, L.A. Experimental study of thermal and catalytic pyrolysis of plastic waste components. Sustainability 2018, 10, 3979. [CrossRef]

31. Gunasee, S.D.; Carrier, M.; Gorgens, J.F.; Mohee, R. Pyrolysis and combustion of municipal solid wastes: evaluation of synergistic effects using TGA-MS. J. Anal. Appl. Pyrolysis 2016, 121, 50-61. [CrossRef]

32. Chen, D.; Zhou, J.; Zhang, Q. Effects of heating rate on slow pyrolysis behavior, kinetic parameters and products properties of moso bamboo. Bioresour. Technol. 2014, 169, 313-319. [CrossRef] [PubMed]

33. Westerhout, R.W.J.; Balk, R.H.P.; Meijer, R.; Kuipers, J.A.M.; van Swaaij, W.P.M. Examination and evaluation of the use of screen heaters for the measurement of the high temperature pyrolysis kinetics of polyethene and polypropene. Ind. Eng. Chem. Res. 1997, 36, 3360-3368. [CrossRef]

34. Bockhorn, H.; Hentschel, J.; Hornung, A.; Hornung, U. Environmental engineering: stepwise pyrolysis of plastic waste. Chem. Eng. Sci. 1999, 54, 3043-3051. [CrossRef]

35. Sørum, L.; Grønli, M.G.; Hustad, J.E. Pyrolysis characteristics and kinetics of municipal solid wastes. Fuel 2001, 80, 1217-1227.

36. Bockhorn, H.; Hornung, A.; Hornung, U. Stepwise pyrolysis for raw material recovery from plastic waste. J. Anal. Appl. Pyrolysis 1998, 46, 1-13. [CrossRef]

37. Dou, B.; Wang, K.; Jiang, B.; Song, Y.; Zhang, C.; Chen, H.; Xu, Y. Fluidized-bed gasification combined continuous sorption-enhanced steam reforming system to continuous hydrogen production from waste plastic. Int. J. Hydrogen Energy 2016, 41, 3803-3810. [CrossRef]

38. Das, P.; Tiwari, P. Valorization of packaging plastic waste by slow pyrolysis. Resour. Conserv. Recycl. 2018, 128, 69-77. [CrossRef]

(C) 2019 by the authors. Licensee MDPI, Basel, Switzerland. This article is an open access article distributed under the terms and conditions of the Creative Commons Attribution (CC BY) license (http://creativecommons.org/licenses/by/4.0/). 